\title{
Uma nova Scientia Traductionis A new Scientia Traductionis
}

Aos cinco anos de existência, Scientia Traductionis busca sua maioridade e ressurge renovada. Nascida em 2005 como revista acadêmica discente do programa de Pós-Graduação em Estudos da Tradução da UFSC, refez agora sua linha editorial, almejando ampliar a divulgação dos trabalhos produzidos no marco deste campo do saber de contínua expansão.

A partir desta edição de $n^{0} 7$, Scientia Traductionis se apresenta com 6 distintas seções. A primeira delas, Trabalhos traduzidos, é inovadora por republicar trabalhos anteriormente publicados em língua estrangeira (e sempre que possível acompanhados dos originais), o que se justifica pela divulgação em português de textos relevantes deste campo e/ou de difícil acesso. Scientia Traductionis também continuará apresentando As outras seções são: Artigos, Traduções comentadas, Críticas de tradução, Ensaios e Entrevistas. Compromissada com o plurilinguismo e a diversidade, publica seus textos em português, espanhol, italiano, francês, inglês e alemão, e está aberta a contribuições de acadêmicos, críticos e tradutores.

E uma última palavra sobre o título de nossa revista. A latinidade de seu nome provoca uma ambiguidade sobre a natureza da tradução e sua concepção hodier-
In the fifth year of its existence Scientia Traductionis reaches its maturity and reemerges renewed. Begun in 2005 as a student academic journal created at the Postgraduate Translation Studies programme $(\mathrm{PGET})^{1}$ at UFSC - Universidade Federal de Santa Catarina - it now has revamped its editorial line with the aim of broadening the dissemination of texts produced in this field of scholarship in continuous expansion.

Starting with this $7^{\text {th }}$ issue, Scientia Traductionis features 6 distinct sections. The first, Translated texts, is innovative in that it focus on the republication of texts previously published in foreign languages in Brazilian Portuguese (whenever possible accompanied by their original versions). The justification for that lies in the need to disseminate relevant texts in our field whose access may be difficult to a Brazilian audience. Scientia Traductionis will also the sections Articles, Translations with commentaries, Essays and Interviews. Commited to plurilingualism and diversity, Scientia Traductionis publishes texts written in English, French, German, Italian, Portuguese and Spanish, and is open to contributions from scholars, critics and translators.

One last word about the title of our journal. Its Latinity brings about an ambiguity about the nature of translation and, at the same time, its hodiernal concep-

\footnotetext{
${ }^{1}$ http://www.pget.ufsc.br/?1=en
} 
na, ao mesmo tempo que evoca seu passado, quando as atividades humanas eram grosso modo concebidas como artes liberales e artes mechanicae, as primeiras, não lucrativas, constituindo ramos do conhecimento próprios da educação do homem abastado, em oposição às segundas, que representavam as atividades manuais, mormente comuns ao vulgo. Embora as artes, nas quais o conhecimento teórico estava acoplado às habilidades práticas, fossem concebidas como algo distinto das scientiae, que tratavam do conhecimento especulativo, há um tangenciamento entre artes liberales, em cuja base se encontram a gramática e a retórica, e scientia. De onde também a possibilidade de se conceber a reflexão sobre a atividade da traductio como uma ars scientifica, lato sensu, seja, como scientia traductionis (seu nome em latim impede, aqui, uma concepção acadêmica de tradução como ciência, stricto sensu, e seu rigor atribuído a certas ciências contemporâneas).

Boas leituras!

Mauri Furlan

Editor-chefe tion evokes its past, when human activities were grosso modo conceived of as artes liberales and artes mechanicae; the former were non-lucrative activities that constituted the fields of knowledge pertinent to the education of the wealthy man, in opposition to the latter which represented the manual activities ordinarily reserved to the common man. Although the artes - where theoretical knowledge was coupled with practical skills - were conceived as something distinct to the scientiae - which dealt with speculative knowledge there is an approximation between artes liberales, in whose base grammar and rhetoric lie, and scientia. Thence, the possibility of thinking about the activity of traductio as an ars scientifica, lato sensu, that is, as scientia traductionis (its Latin name disavows here a scholarly conception of translation as science, stricto sensu, and the rigor ascribed to certain contemporary sciences). reading!

May you have a pleasant

Mauri Furlan

Editor-in-Chief 